\title{
The Development of Small and Medium Enterprises - Their Impact on the Growth of Employment in Kosovo
}

\author{
Prof.Ass.Dr. Hysni Terziu \\ Prof.Ass. Dr. Isuf Lushi \\ University of Prizren "UKSHIN HOTI", Prizren, Kosovo
}

Abstract

The development of small and medium enterprises (SME) at a satisfied level can be achieved only through the application of knowledge and best practices that are developed at private sector, considering as their main derivation - the creation of new work places. The purpose of this paper is that even in our theory and practice to be provided modern concepts regarding the management of small and medium enterprises and regarding the business decision making. Small and medium enterprises can be considered as engines for the creation of new working places, in other words, can be considered as incubators for innovation and entrepreneurship. But in many poor countries, small and medium enterprises are not considered as the main players in the local ecosystem, which makes many of them operating outside the formal legal system and which phenomena results in the increase of informality and in the decrease of productivity. In addition, the condition becomes harder as they lack the funding and the long-term capital which on the other hand are the basis for the creation and function of companies. The development of SMEs is considered as the basic generator of economic growth. This development should be based on the advantages which should be further developed and on the obstacles and weaknesses, which, through strategies and means of economic policy, must be overcome and revitalized. Based on our studies, in the overall context of this work can be conducted the structuring of SMEs and the process of making business decisions in Kosovo. The focus of the analysis in this paper is the creation of friendly conditions for the development of small and medium enterprises towards employment policies and structural reforms, institutional market economy, generating of new work places. The necessity of these actions lays on the fact that in Kosovo exists a very large army of unemployed youth. The world today is undergoing through a global financial crisis which had started in the United States in 2008 and which has spread all around the globe. It can be said that this global financial crisis has been the longest that this world has recognized. For this reason, to the government of any country is added one more task, which is even more difficult, that through its policies to do the impossible in order to overcome this crisis and to send the respective country towards economic development, more specifically towards the development of the small and medium enterprise which in turn will have an impact on the decrease of unemployment. In addition, the purpose of this study would be to identify the current situation of small and medium enterprises, their structuring and their components in Kosovo.

Keywords: Small and medium enterprises, Kosovo, development, employment, economy, wealth-fare, strategy, policy, government

\section{Introduction}

The fall of the economic socialist system in the beginning of the 90's, opened the road for the development of the private sector through several forms such as the privatization of socially-owned enterprises, the growth and expansion of small businesses -mainly family businesses and the establishment of new private enterprises. The establishment and the growth of new private enterprises in the transition countries were characterized with difficulties and with many challenges. In the early 1990s there were conducted many theoretical and empirical researches in order to show the low efficiency found in the planning system of these enterprises into the system of the socialist countries. The lack or the limitation of private enterprise, the abandonment of the centralised system and the adaptation of the market economy system, the abandonment of the free private initiative, confirmed that the expectations for significant improvement of the economic performance at both the macro and the micro level for these countries were desperate (Roland, 2000) ${ }^{1}$. If the state as entrepreneur was not better than the private one, then their new role for creating conditions for private entrepreneurship becomes crucial. Furthermore, from the initial euphoria for the arrival of the market economy system and of the economic freedom, was caused a sudden crisis that very few people had thought about. It became clear that the freedom to deal with entrepreneurship in the conditions when the state restrictions were removed does not mean that the state and the

1 Roland, G., Transition and Economics: Politics, Markets, and Firms, Cambridge, MA: MIT Press, 2000 
representative institutions should not be active as regulators. If that happens than the situation of entrepreneur chaos can last.

The systematic changes that happened in the transition economies provided opportunities for the development of enterprises. As a result of the removal of legal barriers for the private enterprise in these transition economies, then different entrepreneurs started the transformation process in different phases and ways. It is understood that in the beginning of the process, these entrepreneurs has small and medium businesses that were very little oriented toward growth. In the beginning, these entrepreneurs were oriented more towards trade and the service sectors. Later, during the other phases of the transition, they were transformed from small sellers to that kind of sellers that were oriented totally to long-term engagement to economic activities. The difference between these two kinds of entrepreneurs is very important for policy proposals that deal with the promotions and the growth of Small and Medium Enterprises (now one referred as SMEs) during different phases of transition. So in this case, should be pronounced and recognized the role of governmental institutions on the promotion of enterprises and especially of the key sectors which are essential for the development of the country.

The road of Kosovo towards progress and development for a possible integration into European Union is very complicated and challenging especially after the damages that happened during the civil war in 1999. The high inflow of assistance provided from different international organizations for general development after the war has started to decrease now, leaving to Kosovo the challenge for the stabilization and the empowerment of its economy and the increase of capacities of the population and of work force, connected to economic development and fair allocation.

It should be also accepted that the war has caused the "brain-drain" at considerable level and has also decreased the effect of the educational system in Kosovo. Today, businesses in this country need a sophisticated work force, characterized with high technical and managerial skills, but this issue is not taken seriously at institutional level. In addition, the private enterprises in Kosovo do not implement the most advanced managerial practices or the best practices for marketing strategies, promotional strategies or those for informative systems. Most of the entrepreneurs and managers develop their business objectives and concepts without preparing in advance a plan or a strategy. Feasibility studies are very rare.

Taking into consideration the changes in economic and political system that happened during the period after the war in Kosovo, this article is expected to affect the decision-makers on the development of policies that would improve the business environment and doing business in Kosovo.

\section{The current economic situation in Kosovo and in the region}

Uncertainties from the previous years continued to be present in the global economy also during the years of 2014 and 2015. These uncertainties are pronounced mostly in the economies of the Eurozone which grew in 2014 but at a lower pace compared to the previous year. The contributors of the economic growth in the Eurozone were mainly the exports, while the problems of public finances continue to be the main source of uncertainty in some economies of Eurozone. The economic growth in the Southeast Europe (SEE), among which is included also Kosovo, recorded an increase of $6.0 \%$ in 2014. The sectors that contributed to this growth were the sectors of energy (energy production), trade, financial sector, and the agriculture sector.

Regarding the countries of the Eastern Europe, they also have gone through the economic crisis like the Eurozone countries, due to the high level of economic integration that these two regions have. During the period of the crisis, except Albania which recorded a positive economic growth of 3.3\%, all the other economies of the Southeast Europe have recorded lower growth, but it is important that it was not negative, e.g. Croatia recorded the highest growth of $5.8 \%$ while FYR of Macedonia recorded the lowest growth of $0.8 \%$. But 2010 was not characterized with positive growth. Croatia, Romania and Montenegro had negative growth of GDP (IMF, 2010). Despite the fluctuations of economic growth in the region, Kosovo was characterized with positive but very low GDP growth. The current level of GDP in Kosovo is $€ 4.2$ billion, which is twice less than Albania and three times less than Bosnia and Herzegovina, making it one of the poorest countries in the region (IMF, 2010).

Despite the fragile situation in the external sector, Kosovo's economy in 2014 continued to expand, recording a rate of real growth of about $4 \%$. The main carrier of the country's economic growth was the private sector, through the increase of 
consumption and investments. In this regarded also the investments in public sector had an important positive impact on the growth of the economy.

On the other hand, the rise of the prices at global level was reflected also in the economy of Kosovo, where the average inflation rate for 2014 was $7.3 \%$. The main causes of the increase of overall prices were the rise of prices for food products and oil, which are also the main products that are imported in our country. Kosovo's economy continues to be characterized by a high level of current account deficit, which is mainly caused by the trade deficit. The relatively low level of exports and the high level of imports caused that the trade deficit to reach a value of around $€ 2.2$ billion in 2014. Unlike the trade in goods which is highly negative, the trade for services is characterized by a positive balance which is preventing the further deepening of the deficit. Significant contribution to the narrowing of the current account deficit, continue to play the transfers from abroad, especially remittances. Lastly, within the capital and financial account, as the main category continues to be the Foreign Direct Investments (FDIs), which in 2011 recorded a growth of $14.4 \%$.

\section{The main economic indicators and the growth of private sector}

The evidences show that the Government's decision of 2008 to increase the level of public investments for more than $120 \%$ was the main driver of economic growth. Furthermore, this reallocation of resources towards the public investment has been a stimulus for the economy to record an increase of over $4 \%$ in 2009 , a period when most of the other countries in the region were facing economic decline. Due to the relatively low level of integration into the global economy and due to weak fiscal policy, the Kosovo's economy has been significantly protected from the Global Financial Crisis of 2008.

Based on the reports of the World Bank ${ }^{1}$, during the recent years, a large part of the economic progress has been from the donor aids and remittances, which cannot be the basis for sustainable economic strategy. Poverty continues to remain a problem in Kosovo. Based on the reports of UNDP2, the unemployment rate in Kosovo is about $43 \%, 34 \%$ of people live in poverty with less than 1.41 Euros per day, while $18 \%$ of the people live in extreme poverty with less than 0.94 Euros per day.

The number of new entrants in the labour market is very high compared to neighbouring countries, because Kosovo has more than $70 \%$ of the population under the age of 35 . It is estimated that the number of young people who enter every year in the labour market is that big that required at least a real economic growth of $7.0 \%$, in order to be able to absorb all these new entrants and to contribute on the reduction of unemployment ${ }^{3}$. According to the Progress Report of European Commission $^{4}$ for Kosovo in 2014, is indicated that despite the economic growth that Kosovo is having, it is not creating enough jobs to absorb the new entrants and to reduce the pressure on the labour market. Since a large number of new jobs places can be created by SMEs, through the establishment of new SMEs and the growth of the existing ones, then the successful implementation of the SME Strategy will be the main contributor for the economic growth in Kosovo.

Table 1: The main macroeconomic indicators planned for the period 2008-20145

\begin{tabular}{|l|l|l|l|l|l|l|l|}
\hline Decryption & 2008 & 2009 & 2010 & 2011 & 2012 & 2013 & 2014 \\
\hline Consumption in mil. euro & 3.912 .8 & 4.218 .2 & 4.325 .0 & 4.652 .1 & 5.104 .3 & 5.437 .9 & 5.742 .9 \\
\hline Investments in mil. euro & 1.123 .7 & 1.340 .3 & 1.405 .0 & 1.565 .0 & 1.422 .3 & 1.460 .2 & 1.397 .9 \\
\hline Neto Exports in mil. euro & 1.420 .4 & 1.536 .1 & 1.525 .8 & 1.622 .4 & 1.576 .7 & 1.665 .2 & 1.748 .8 \\
\hline GDP in mil. Euro & 3905 & 3912 & 4289 & 4639 & 4978 & 5214 & 5501 \\
\hline Real Growth of GDP, in \% & 6.9 & 2.9 & 4.0 & 5.3 & 5.1 & 5.4 & 6.0 \\
\hline GDP per capita, in mil. Euro & 1847 & 1848 & 1966 & 2127 & 2249 & 2321 & 2412 \\
\hline Inflation, in \% & 9.2 & -2.4 & 3.5 & 5.3 & 2.1 & 1.5 & 1.4 \\
\hline
\end{tabular}

1 World Bank, Country Partnership Strategy for the Republic of Kosovo for the period fy12-fy15, May 2012

2 UNDP, Kosovo Human Development Report 2014

3 Ministry of Trade and Industry, Strategy for development of privat sector in Kosovo, February 2013

4 European Commission, Progress Report 2014 for Kosovo, October 2014

5 Ministry of Economy and Finance, Department of Economic Policy and Public Finance International Cooperation, Macroeconomics

Unit, Kosovo Economic Bulletin January - June 2015, Prishtine 


\section{The strategy for SME development in Kosovo}

Starting from 2005, the Government of Kosovo has adopted a considerable number of strategies. Among the most important strategies can be mentioned: the Strategy for Employment, the Strategy for Energy, the Strategy for the Development of Higher Education, the Government Programme, the Action Plan for the Prevention of Informal Economy in Kosovo, among others. The Strategy for the Development of the Private Sector was prepared in 2008, but is not approved by the Government of Kosovo.

The development of SMEs is mentioned in the Strategy for the Development of the Private Sector ${ }^{1}$ as one of its components, but it is not associated with any Implementation Plan. For the preparation of the Strategy for SMEs, were consulted all the other relevant strategies. However, all the other strategies adopted so far are associated with Implementation Plans. The possibility for successful implementation of the strategy is a function of the connections between the activities described in the Implementation Plan and relevant objectives.

The strategy for SME development in Kosovo is based on the European Act for Small Businesses. This Act is a key policy document for the development of SMEs in Europe. Kosovo respects the guidelines and rules of the EU since 2002, when it was also created the Department for the Development of the Private Sector. Since the establishment of the Agency for SME Support in 2006, Kosovo has been officially included in the European Charter for SMEs that rely on the same document of 2000. The success of the European Charter for SMEs is reflected in the European Act for Small Businesses, which has put the SMEs' policy at the centre of economic and administrative decision making. It is also considered a success for the EU in general and for the SMEs in Europe in particular. In fact, this strategy is an important tool for the implementation of the Act for Small Business and for leading the process for the reform of the Kosovo's economy and for the establishment of SMEs at the centre of economic and administrative decision-making here. SMEs are and will be the engine for economic development that will provide new working places, economic growth and economic prosperity but only under a suitable economic framework.

According to the data from Kosovo Business Registration Agency (KBRA) ${ }^{2}$ - the number of SMEs registered until December 31,2011 was 103,755 . All these SMEs employ 216,799 workers or $79.59 \%$ of total employees in the private sector or $62.24 \%$ of total employment in Kosovo.

The size of SMEs in Kosovo is defined by the Law no. 2005/02-L5³ and by the Law no. 03/L-031 for the support of Small and Medium Enterprises. The number of employees is the sole criteria for the classification of enterprises by size in Kosovo. This presents the difference with the EU countries where in addition to the number of employees is taken into consideration also the annual turnover. The following table provides the spectrum of registered enterprises in Kosovo on the basis of the number of employees.

Table 14: Registered Enterprises in Kosovo based on the Numbers of Employees - 2011

\begin{tabular}{|l|l|l|l|}
\hline Classification according to size & $\begin{array}{l}\text { According to the number of } \\
\text { Employees }\end{array}$ & $\begin{array}{l}\text { According to the number of } \\
\text { Enterprises }\end{array}$ & $\%$ in Total \\
\hline Micro & $1-9$ & 102,070 & 98.37 \\
\hline Small & $10-49$ & 1,406 & 1.35 \\
\hline Medium & $50-249$ & 221 & 0.22 \\
\hline Big & 250 and more & 58 & 0.06 \\
\hline Total & 103,755 & 100.00 \\
\hline
\end{tabular}

1 Ministry of Trade and Industry, Strategy for development of privat sector in Kosovo, February 2013

2 Ministry of Trade and Industry, Agency for the registration of small and medium enterprises in Kosovo, Annual Report 2015

3 Republic of Kosovo Assembly, 2005/02-L5: Law on Support to Small and Medium Enterprise, March 2005

4 Ministry of Trade and Industry, Agency for the registration of small and medium enterprises in Kosovo, Annual Report 2015 
If we provide an overview of the registered enterprises according to the region, is noted that the region of Prishtina has about $36.96 \%$ of the registered businesses at the national level, follow by the region of Gjilan with $20.78 \%$, Prizren with $15.18 \%$, Peja with $16.45 \%$ and finally Mitrovica with $10.64 \%$.

Figure 11: Enterprises registered in Kosovo according to Region, in \%

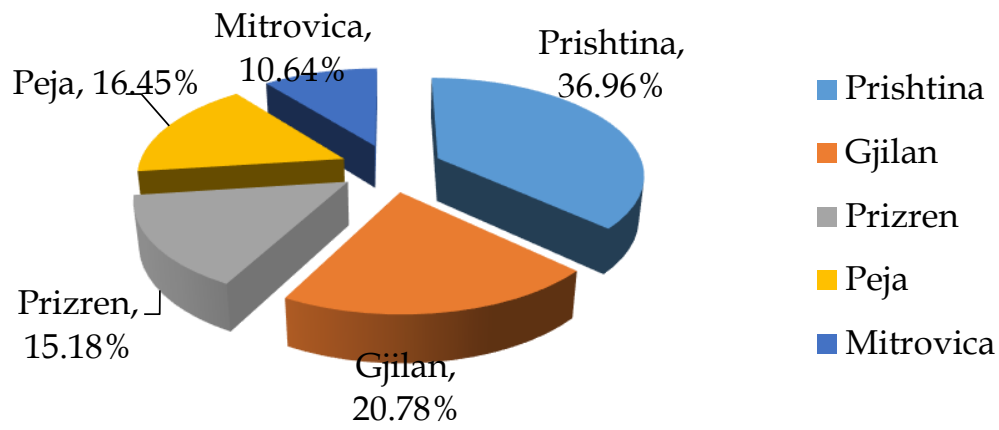

The data provided by Kosovo Business Registration Agency (KBRA) and presented by the following table, provide information related to the structure of ownership of registered enterprises in Kosovo. Individual Businesses clearly dominate the ownership structure with $90 \%$. The rest of the companies are general partnership (3.2\%), limited liability companies $(5.8 \%)$, foreign-owned enterprise $(0.46 \%)$ and joint stock companies $(0.35 \%)$.

Certainly the type of the ownership presented below shows the shortcomings of SMEs in Kosovo, because it shows the reluctance of SME owners to bring together financial and human capital in the most advanced forms of business.

Table 32: SMEs according to structure of Ownership in Kosovo

\begin{tabular}{|l|l|l|l|}
\hline No. & Structure of Ownership & Number of Enterprises & $\%$ in Total \\
\hline 1. & Individual Businesses & 93,129 & 90.00 \\
\hline 2. & General Partnership & 3,383 & 3.20 \\
\hline 3. & Limited Partnership & 90 & 0.08 \\
\hline 4. & Limited Liability company & 6,170 & 5.80 \\
\hline 5. & Joint-Stock Companies & 368 & 0.35 \\
\hline 6. & Foreign owned enterprises & 486 & 0.46 \\
\hline 7. & Social Enterprises & 16 & 0.01 \\
\hline 8. & Public Enterprises & 12 & 0.01 \\
\hline 9. & Agricultural Cooperative & 68 & 0.06 \\
\hline 10. & Other - under the jurisdiction of Kosovo Privatization & 33 & 0.03 \\
\hline Total & Agency & 103,755 & 100.00 \\
\hline
\end{tabular}

On the other hand, the registration of businesses according to time periods, 1999-2005 and 2005-2014, shows a significantly positive change in the structure of business registration in the second period. This positive change is as a result of the awareness of businesses for the most advanced forms of capital merger and of tools in favour of general partnerships, joint ventures and particularly of limited liability companies which marked a significant increase in this period.

1 Ministry of Trade and Industry, Agency for the registration of small and medium enterprises in Kosovo, Annual Report 2015 2 Ministry of Trade and Industry, Agency for the registration of small and medium enterprises in Kosovo, Annual Report 2015 
In the period $2008-2014$ were closed 4,177 businesses, namely $8.54 \%$ of total number of registered businesses in this period. Regarding the businesses that failed or got de-registered, we must emphasize that this data should be taken with great reserve because under the current law, if a business wants to change the form of ownership it must firstly be deregistered and then to be registered again in the new form of ownership.

In addition, the informal economy prevents the fair competition and increases the relative costs of enterprises that operate in the formal sector. The informal labour contracts and the systematic evasion of social security, contributes to the weaken of labour protections and decreases their social gains. They also have a negative impact on the fiscal budget and on the entire social infrastructure due to the decrease of revenues and a subsequent reduction of proper public services.

According to the "Government Programme for the Prevention of the Informal Economy in Kosovo for 2013-2014"1, the estimated size of the informal economy ranges from $39 \%$ to $50 \%$ of GDP.

Table 42: Annual Turnover according to the Size of Enterprises and of GDP, 2014

\begin{tabular}{|l|l|l|l|}
\hline Size of Enterprises & Number of Enterprises & Turnover $(€)$ & Participation in GDP $(\%)$ \\
\hline Micro & 14,968 & $656,885,164.33$ & 16.79 \\
\hline Small & 1210 & $667,585,914.82$ & 17.07 \\
\hline Medium & 185 & $369,455,655.16$ & 9.44 \\
\hline Big & 58 & $528,558,359.84$ & 13.51 \\
\hline Total & 16,421 & $2,222,485,094.15$ & 56.81 \\
\hline
\end{tabular}

Based on the data from the Tax Administration of Kosovo (TAK) ${ }^{3}$, presented in the table above, the total SME turnover in 2014 was $€ 16.4$ million or $43.3 \%$ of GDP. Total turnover of all businesses, including big businesses, was $€ 2.2$ million or $56.81 \%$ of GDP.

Figure $2^{4}$ : The participation of SMEs in GDP, in \%

Total,

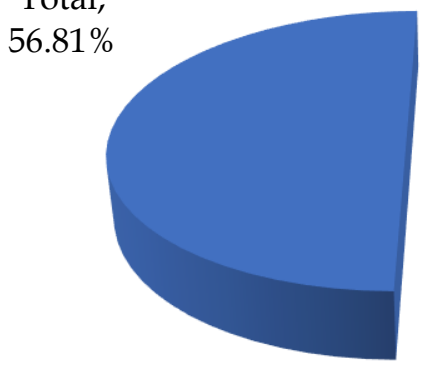

Micro,

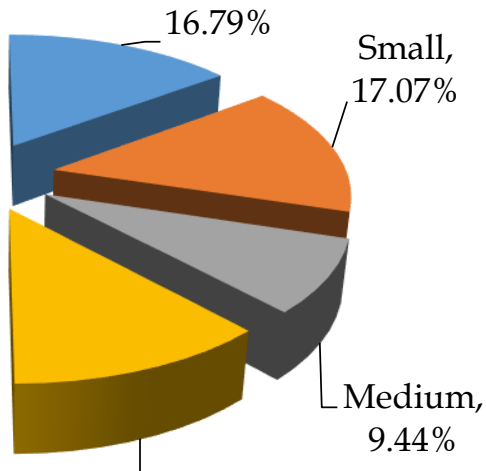

Big, $13.51 \%$

1 Office of Prime Minister Kosovo, Action Plan of the Economic Vision of Kosovo 2011-2014, July 2011

2 Tax Administration of Kosovo, Report 2014

3 Tax Administration of Kosovo, Report 2014

4 Tax Administration of Kosovo, Report 2014 
In the European Commission's Progress Report for Kosovo 2010', were identified three main barriers with which were faced the businesses in Kosovo. The first barrier is related to the unreliable and unstable supply with electricity and water which are particularly serious for the SMEs that deal with production. Also, the other main barriers for the rapid development of SMEs are considered the limited access to financial resources. The third barrier is the insufficient rule of law, which affects also all the citizens of Kosovo.

However since 2008, there were also a number of important achievements which have resulted in the improvement of business environment for SMEs in Kosovo. In the past years (since February, 2008 when Kosovo declared its independence) were conducted tax reform and was reorganized the process of VAT collection through fiscal arcs, despite oppositions that came from some business associations. These were important developments in terms of reducing the level of informality in the SME sector and the improvement of relations between the business community and the state. The tax revenues have significantly increased due to the lower of tax rate from $20 \%$ to $10 \%$, and also due to the improvement of law enforcement, expansion of the tax base and due to the better reorganization of tax collection process ${ }^{2}$.

Significant improvements have been made also in legal and administrative matters and SMEs can now register through the Centre "One Stop Shop" in the respective municipalities. These were established with the support of the World Bank and the European Commission. The Kosovo Business Registration Agency (KBRA) makes online business registration, application for fiscal number, the VAT and import-export permits for small businesses.

\subsection{The strategic goals of the development of SMEs}

Kosovo for the first time, since its involvement in the report of the World Bank "Doing Business"3, marked the greatest progress in the ranking of this list. Compared to last year, when Kosovo was positioned in the 117th place, this year our country is listed as the 98th country on the ease of doing business among 185 countries in total. So, Kosovo has been improved for 19 places in business indicators report, which was released in late 2012 by the World Bank.

The assessment of this report is based on 11 indicators, namely, starting a business, obtaining construction permit, supply with electricity, registering of the property, getting loans, protecting investors, paying taxes, trade across borders, enforcement of contracts, resolving insolvency and the employment of workers.

Kosovo has made progress in the first point which is "starting the business" by eliminating initial capital requirement and the payments for business registration. The protection of investors is strengthened and the process for business registration has been accelerated and simplified, suggested the report "Doing Business"4.

According to the World Bank, the protection of investors has improved by 74 positions, resulting in the largest increase, compared with other indicators in this report. However, progress has been made also in the index on the ease of opening a new business, where we shifted from position 168 (in 2011) to the position 126 (2012). Also the indicator for the trade across borders has been improved by 7 positions.

\subsection{Exports and SME plans for growth and development}

In the new fiscal package for 2014, it was foreseen that for SMEs that deal with export - import to reduce for them the customs procedures and the required documents. So the number of documents required by Customs of Kosovo now is only 3 documents instead of 9 documents as they were before. At the same time, the new law opens the way for the creation of the Division for the Complains for Customs, Tax Administration of Kosovo and property tax. The purpose of the formation of this division was to reduce the time needed to resolve the complaints of businesses (Ministry of Finance, 2011).

1 European Commission, Progress Report 2010 for Kosovo

2 European Commission, Progress Report 2010 for Kosovo

3 World Bank, Doing Business 2015: Going Beyod Efficiency, 2015, Washington

4 World Bank, Doing Business 2015: Going Beyod Efficiency, 2015, Washington 
The data for the trade balance provided by the Central Bank of Kosovo (CBK) ${ }^{1}$ show that Kosovo continues to have a very negative balance. The following data show imports and exports during the recent years and their tendency. Kosovo's trade exchange in 2011 reached a value of $€ 2.7$ billion, an indicator that is higher compared to 2010 for $14.7 \%$. Regarding imports, they amounted to over $€ 2.4$ billion, $15.9 \%$ higher compared to 2010. The exported goods have reached the value of $€ 313$ million, or an increase of $6.5 \%$. For this period, the coverage of imports by exports was $12.6 \%$. Trade with the European Union and with the countries of the region (CEFTA), make up the majority of Kosovo's foreign trade, $72.7 \%$ of total trade.

Table 52: Kosovo's trade balance (in millions of euro)

\begin{tabular}{|l|l|l|l|l|l|l|l|}
\hline Selected Indicators & 2008 & 2009 & 2010 & 2011 & 2012 & 2013 & 2014 \\
\hline Real GDP Growth (\%) & 4.5 & 3.6 & 3.3 & 4.4 & 2.8 & 3.4 & 1.2 \\
\hline GDP (mIn EUR) & 3.710 .7 & 4.077 .0 & 4.136 .5 & 4.486 .0 & 4.949 .9 & 5.232 .9 & 5.392 .0 \\
\hline $\begin{array}{l}\text { Inflation (annual } \\
\text { average) }\end{array}$ & 9.4 & -2.4 & 3.5 & 7.3 & 2.5 & 3.6 & 3.4 \\
\hline Loans (mIn EUR) & 1.183 .4 & 1.289 & 1.458 .7 & 1.698 .1 & 1.763 .4 & 1.805 .8 & 1.882 .4 \\
\hline Deposits (mln EUR) & 1.444 .1 & 1.744 .8 & 1.936 .9 & 2.104 .0 & 2.279 .0 & 2.449 .0 & 2.537 .5 \\
\hline $\begin{array}{l}\text { Exports of goods and } \\
\text { services }\end{array}$ & 547.1 & 683.8 & 781.5 & 907.0 & 948.4 & 944.7 & 1.081 .9 \\
\hline $\begin{array}{l}\text { Import of goods and } \\
\text { services }\end{array}$ & 1.967 .5 & 2.219 .9 & 2.307 .3 & 2.529 .4 & 2.225 .1 & 2.609 .9 & 2.830 .7 \\
\hline
\end{tabular}

According to the research, the number of exporting enterprises in Kosovo remains the same as in 2013. Only $5.17 \%$ of the enterprises export goods and services, while the vast majority of SMEs, approximately $94.61 \%$, were unable to penetrate into the foreign markets. While in terms of certificated for quality standards, only $11.37 \%$ said that they possess it and $1.9 \%$ is in the process of obtaining this certificate (see Table 6).

Table 63: Exporting SMEs and possession of quality standards

\begin{tabular}{|l|l|l|l|}
\hline $\begin{array}{l}\text { Are you an Exporting } \\
\text { Enterprise }\end{array}$ & $\%$ & $\begin{array}{l}\text { Does your SME has the quality standards or } \\
\text { accreditation ISO; ISO 9001; ISO HASAP }\end{array}$ & $\%$ \\
\hline YES & 5.17 & YES & 11.37 \\
\hline NO & 94.61 & NO & 86.73 \\
\hline Other & 0.22 & In the process of standardisation & 1.90 \\
\hline Total & 100.00 & Total & 100.00 \\
\hline
\end{tabular}

Enterprises face various obstacles during their exporting and importing activities. The obstacles and problems are reflected in the following table considering the data from the 2014 research.

1 Central Bank of Kosovo, Annual Report 2014, June 2014

2 Ministry of Economy and Finance, Department of Economic Policy and Public Finance International Cooperation, Macroeconomics

Unit, Kosovo Economic Bulletin January - June 2015, Prishtine

3 Business Support Centre Kosovo, SME Survey 2010 and 2011, Prishtine 
Table 71: The main obstacles to export according to the answers, expressed in $\%$

\begin{tabular}{|l|l|}
\hline Main Obstacles & $\%$ \\
\hline 1. Lack of personal documentation (e.g. Visa) & 10.3 \\
\hline 2. Delays at the border & 9.9 \\
\hline 3. Lack of information on market & 9.4 \\
\hline 4. Lack of infrastructure & 9.4 \\
\hline 5. Political Risk & 9.4 \\
\hline 6. Inadequate Legislation & 8.9 \\
\hline 7. Certificate on the Origin of the good & 8.9 \\
\hline 8. Inefficient Functions of Banks & 8.9 \\
\hline 9. Respect of the Contacts & 8.5 \\
\hline 10. Implementation of reciprocity & 8.5 \\
\hline 11. Certificate on quality & 8.0 \\
\hline Total & 100.0 \\
\hline
\end{tabular}

If we refer to the indicators of total import and export of Kosovo, it is shown that the EU has an important place in the country's trade balance. Thus, according to the destination (group of countries), in 2014, the trade turnover with the EU accounts for $38.5 \%$ of total trade or around $€ 1.07$ billion. This figure is $12.9 \%$ higher compared to 2013 . The value of import is over $€ 940$ million or $37.9 \%$ of total import value, marking an increase of $14.5 \%$ compared with the same period of 2013 . Within the EU countries, we have a predominance of imports from these countries:

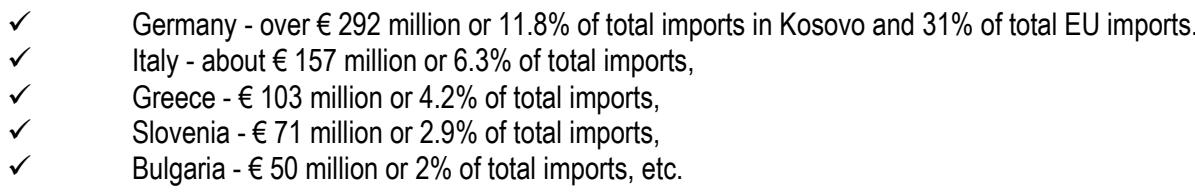

But in terms of volume of exports by destination, in 2014 most of the exports of Kosovo have been oriented towards EU countries, amounting to $€ 135$ million or $43.2 \%$ of total exports. The three most important countries mentioned below (Italy, Germany and Slovenia), cover $84 \%$ of total EU exports. Ranking of countries is as follows:

$\checkmark \quad$ Italy is regarded as the most attractive country for exports, and covers $62 \%$ of Kosovo's exports to the EU and $26.7 \%$ of total exports,

$\checkmark \quad$ Germany ranks as the second covering $17 \%$ of total EU exports and $7.5 \%$ of total exports,

$\checkmark \quad$ Slovenia ranks the third with $4.4 \%$ of total EU exports and $1.9 \%$ of total exports.

It should be pointed out that in 2014 there is a significant drop in the volume of exports towards Belgium for $55.6 \%$ and Bulgaria for $87.8 \%$, countries that have previously covered a relatively large part of the value of exports towards EU countries.

\subsection{The structure of Exports and Imports}

Regarding the structure of exports, it still remains the same. It is mainly realized in the form of raw materials and unfinished products. Exports are dominated by base metals and are as follows:

○ the mineral products in 2014 covered $73 \%$ of total exports (iron and steel, copper and copper articles)

- machinery and mechanical equipments occupy $4.8 \%$ of total exports,

1 Business Support Centre Kosovo, Entrepreneurship and Small Business Development in Kosovo in 2013: Research report, 2013, Prishtine 
prepared foods and beverages (alcoholic) represent $4.1 \%$ of exports to Kosovo

plant products occupy $4 \%$ of total exports,

plastics, rubber and related items cover $4 \%$ of total exports,

Textiles account for $3.5 \%$ of total exports.

The structure of imports remained similar to last year, being dominated by these categories:

- Group of mining products, prepared foods, beverages and tobacco as well as the category of machinery and equipment totalling to a value of $€ 1.1$ billion or $44.7 \%$ of total imports.

- Group of food products, which consists mainly of agricultural products - livestock and food industry, occupy $22.6 \%$ of total imports in Kosovo reaching to a value of $€ 560$ million. This group of food products is dominated by beverages, alcohol and vinegar, tobacco and manufactured tobacco substitutes, meat and meat-based products, cereals, sugar and sweets, dairy products, etc.

\section{Conclusions and Recommendations}

The conclusions that derived from the conducted analysis are as follows:

- $\quad$ From the structure of ownership point of view, most of the businesses are organized as individual businesses (89.4\%). Only $8.3 \%$ of the companies in the sample are organized as business partnerships and $1.8 \%$ as shareholders. These new data confirm that the business partnerships are not a common practice among SMEs in Kosovo.

- There exist large differences in terms of business ownership by gender. The research results show that only $6 \%$ of businesses are owned by woman. This suggests a low level of women as entrepreneurs.

- In terms of partnership in business, approximately $66 \%$ of entrepreneurs said they have family relationships, $15 \%$ have a professional relationship, and $15 \%$ were joint financing. These statistics are a concern for the development of the SME sector.

- Nearly $48 \%$ of companies stated that their turnover decreased in 2015 . From the total SMEs, $22 \%$ think that they did not have changes in turnover while $30 \%$ marked increase in turnover compared with 2014 . The survey results show an increase in total assets in 2015 compared to 2014. This increase is followed by fixed assets and working capital investment in land.

- The research results show an increase in investments by $28 \%$, in 2015 compared to 2014 . About $61 \%$ of investments were financed from domestic sources, suggesting the importance of inner financial resources for the growth of the SME sector in Kosovo and a lower role of the banks to support the financial needs of SMEs.

- $\quad$ According to the managerial level (general manager and department manager) about $47.36 \%$ of employees in SMEs have high school and the rest or $45.34 \%$ are with vocational school or general school.

- According to the findings of 2015, the most important strategy for business in Kosovo is the improvement of the quality of products and services (47.7\%), followed by the strategy for the reduction of cost $(19.5 \%)$, strategy for marketing and promotional activities (14.8\%), strategy for the advancement of technology and equipment (10.9\%), and strategy for increasing the skills of employees for better performance $(7.0 \%)$.

\section{Recommendations}

According to the analysis made in this study, it appears that for the support of SMEs in the development of entrepreneurial activities or strategic management activities are provided the following steps: 
- $\quad$ The first step is to encourage as many SMEs to enter the formal sector. With the introduction of the regulatory procedures for businesses, a greater number of SMEs will be encouraged to enter the formal economy. This should provide to SMEs greater opportunities to access the credit and financial opportunities and greater possibilities to solve the commercial problems, while on the other hand to contribute on the overall development of the market economy and on the creation of sustainable jobs in the SME sector.

- The second step is to improve the facilitation of business closure or to change the registration forms by ownership. It is extremely important to take initiatives in this area to ensure that the honest entrepreneurs can start off their businesses after they failed in a particular area, or has changed the form of ownership towards more advanced forms of business development.

- $\quad$ The third step is to organize a campaign to empower the role of women in the establishment and development of sustainable enterprises.

- The fourth step that is accepted is that companies should provide training and education to employees in order to empower them and to engage them in changes.

- The fifth step is the development of the vision and business mission (short and long term strategic objectives, alternatives and flexible strategies from environmental change, etc.) from the senior management team.

- $\quad$ The sixth step also recommends to the firms that they must effectively use new technology (manufacturing and information technologies), to engage in available strategies (by using global markets and cooperative strategies), to develop a flexible structure (e.g. horizontal) and to develop a culture that emphasizes organizational learning.

- The seventh step suggests the use of innovative approaches to address changes in the enterprise. The management should assess the impact of change on employees and on their company. This step forces managers to establish criteria for predicting the success of the changes before the implementation begins.

\section{Summary}

Kosovo is now going through a late period of transition challenge, where the development of the new private sector plays and will continue to play a crucial role in the recovery and development of the economy. This can be illustrated by the fact that majority of private initiatives, such as family businesses, have experienced a rapid expansion in the years of transition, especially in the trade sector. This was not as the result of favourable conditions and of appropriate environment, but due to the acts of Kosovo entrepreneurs in the sector in which with smaller investments can realize profits, and because of rapid turnover of capital.

Economic policies in Kosovo as presented in Governmental Development documents, determine the need for the development of safe and unimpeded private sector, but nevertheless, the sector of small and medium enterprises (SMEs) still has not won the needed affirmation and support which is very common for the developed countries and for some countries in transition.

The sector of SMEs is of great importance because it is a flexible sector and capable to create new jobs. Also this sector is quite profitable in domestic revenues, beneficial for Kosovo's budget, GDP etc. They are advantages because operating with local assets; both the material and human assets. During the exercise of their activities in Kosovo they have their own advantages for using a cheap labour force, etc.

Due to the unfavourable environment for business that dominated in the past, due to the lack of cultural and creative entrepreneurship and due to the lack of investment in Research and Development, Kosovo lacks innovative firms with rapid growth, which are key contributors to creating of jobs in developed economies.

Kosovo has a great potential for the development and progress. It has a central location in the region. It is located among a potential market in Europe with 100 million people. It is rich in natural resources and is characterized with a very young workforce motivated by a strong entrepreneurial spirit. It has a powerful Diaspora that continues to keep Kosovo alive through remittances for decades. All these resources only need to be used in a wise and at accelerated pace. It is true that being in step with regional and global players will not be an easy path for Kosovo businesses. 


\section{List of References}

[1] [1] Mustafa M., Development of Small and Medium Enterprises in Kosovo, University of Prishtina, 2004, Prishtine

[2] [2] Kume V., Organizational Structure, Faculty of Economics, University of Tirana, Tirane

[3] [3] Mustafa M., Kutllovci E., Gashi P., Krasniqi B., Small and Medium Business: The creation, management and business growth, Riinvest, 2006, Prishtine

[4] [4] Ministry of Trade and Industry, Agency for support of small and medium enterprises, Annual Report 2014

[5] [5] Ministry of Trade and Industry, Strategy for development of privat sector in Kosovo, February 2013

[6] [6] Ministry of Trade and Industry, Agency for support of small and medium enterprises, Annual Report 2009

[7] [7] Ministry of Trade and Industry, Agency for the registration of small and medium enterprises in Kosovo, Annual Report 2015

[8] [8] Kosovo Agency of Statistics, Statistical Overview of the sector of small and medium enterprises, Report 2014

[9] [9] Kosovo Agency of Statistics, Annual Report 2015

[10] [10] Ministry of Economy and Finance, Department of Economic Policy and Public Finance International Cooperation, Macroeconomics Unit, Kosovo Economic Bulletin January - June 2015, Prishtine

[11] [11] Business Support Centre Kosovo, Entrepreneurship and Small Business Development in Kosovo in 2013: Research report, 2013, Prishtine

[12] [12] Tax Administration of Kosovo, Report 2014

[13] [13] European Commission, Progress Report 2010 for Kosovo

[14] [14] World Bank, Country Partnership Strategy for the Republic of Kosovo for the period fy12-fy15, May 2012

[15] [15] Central Bank of Kosovo, Annual Report 2014, June 2014

[16] [16] Business Support Centre Kosovo, SME Survey 2010 and 2011, Prishtine

[17] [17] European Commission, Progress Report 2014 for Kosovo, October 2014

[18] [18] UNDP, Kosovo Human Development Report 2014

[19] [19] Office of Prime Minister Kosovo, Action Plan of the Economic Vision of Kosovo 2011-2014, July 2011

[20] [20] World Bank, Doing Business 2015: Going Beyod Efficiency, 2015, Washington

[21] [21] Roland, G., Transition and Economics: Politics, Markets, and Firms, Cambridge, MA: MIT Press, 2000

[22] [22] Republic of Kosovo Assembly, 2005/02-L5: Law on Support to Small and Medium Enterprise, March 2005 